\title{
Pesantren as Heart Knowledge Management
}

\author{
Fandy Adpen Lazzavietamsi \\ \{fandy.adven@stkippgritulungagung.ac.id\} \\ STKIP PGRI Tulungagung, Jawa Timur, Indonesia
}

\begin{abstract}
It is the oldest educational institution in Indonesia that existed before 1945, but today it is being driven to the development of a formal educational institution born into the European education system. Formal institutions of education are so focused on building up the potential of human mind that they ignore the potential of the heart. The paper was exploring how education in Pesantrens remained to build up the potential of the human heart through the management of knowledge based on Islam. The research method of string studies is used to describe how the teaching of good that is theoretically given at school has been carried out and developed in the propagation of pesantren for centuries through the management of knowledge of the heart. Wisdom in the mind, word and deed are the objectives of the management based on spiritual values without bounds. Pesantren builds a sense of night, life, and humanity that in time clears the heart up as the mind control of humans who create, share, use and manage knowledge and information.
\end{abstract}

Keywords: Pesantren ${ }^{1}$, Knowledge Management, Heart.

\section{Education And Culture}

Education has increasingly evolved to follow the advances of science and technology, the transformation of the industrial era to the information age has taken place in less than five centuries. The human will is to facilitate the work process has been transformed into increasingly sophisticated technology. The boundaries of space and time have been slowly controlled through science and technology. Education is programmed and implemented on a major consideration for the development of science and technology. Mind becomes a humanitarian measure, as Rene descrastes told us, "cogito ergo sum." [1]. Problems begin to emerge when humanity is fading, social problems like a father/mother who marries their child, religious leaders rape their congregation and others. Within the limits of such humanness education concerned and was an aspect to be considered. The problem was compounded by educational programs organized by the government as rigid in the development of methods aimed at building potential minds for learners.

Indonesia as a developing country must follow the outlying standards of education that apply to the developed world. Whereas each nation hasa different culture in which there are different methods of knowledge, language, social systems, technologies, ways of life, and

1 Pesantren or Pondok Pesantren are Islamic boarding schools in Indonesia. Pesantren provide to Indonesian citizens at low cost; although today some modern pesantren charge higher fees than previously, they are still significantly cheaper than non-pesantren educational institutions. The traditional pattern was for students to work in the headmaster's rice fields in exchange for food, shelter, and education 
different religious systems [2]. Education cannot be separated from culture [3], for it is maintained through those cultural educationally. By and by the features and characteristics of education are influenced by the culture in which a nation exists. So every nation of different cultures has a different educational system. The education system in Indonesia comes from the European education system that has been true since the Dutch colonisation, the implication of a cultural transformation. The original Indonesian education has gradually changed with the education of other nations whose culture differs from theirs.

Pesantren's boarding house as an educational institution has maintained the original Indonesian education, even though it is a blend of buddhist Hindu and islamic education [4]. A local language is used in examining the yellow scriptures that are teaching the natural order of life between man and man and his Lord. The management of knowledge is strictly enforced, every knowledge gained personified by deed or behavior, the creation of science is not easy, and must be passed on clarifications, analyses, and reflections of previously existing science. Focus education is directed at the management of knowledge of the heart through thought, word and deed. In the development of Pesantren is slowly getting replaced and adjusting to the formal educational system that the government has put in place to maintain the presence of the school. But there are still some Pesantrens that have survived with the original Pesantren system that has been in effect for centuries. This school puts a look at the transformation of islamic religious teaching on daily life through the management of knowledgeable hearts. To explore pesantren as the management of knowledge of the heart, a qualitative approach to the research method of phenomena is applied as researchers intend to explore the current pesantren phenomenon with different features. Research was done in some Pesantren, such as salaf Pesantren, modern Pesantren and mixed Pesantren.

\section{Result}

\subsection{The Development of Pesantren}

Every religion require community to preserve the moral values it brings. It will form a tradition that will continue to grow. Hence, the symbiotic relationship between religious values and the traditions of society is a symbiotic relationship that permeates one another. In this regard, it is a symbiotic between the traditional preservation of moral values and even the religious institution (Islam) of society [5]. Pesantren has written its own history and cannot be denied by those who deliberately turn a blind eye to the fact clearly visible to them. Thus, in times of growing secularism, moral degradation and the influx of matalistic souls into the person of our nation. The early part of the Indonesian Muslim majority can be traced to the historical aspect of a relatively long existence. Research on pesantren suggests that it is already here on earth as Islam spread on earth. It has been mentioned that pesantren dates back to the late 14th or early 15 th century, founded first by maulana malik ibrahim who was later developed farther by Sunan Ampel.

History notes that Pesantrens or Pesantrens in pesantren are a longtime public educational, religious, social institution known as a community development. Besides, as agents of social change, and liberation to societies from oppression, moral stagnation, politics, poverty. With the orientation, Pesantren has demonstrated its active participation in paving up the lives of good people pre-freedom to date. And history records the names of shaichana chalil bin abdul latif, k.h. hasyim asya 'ri, k. H wahab hasbullah, k.h. bisyri shamsuri, k.h. saifuddin zuhri and k.h. wahid hasyim are listed as quite a contribution to the Indonesian migration. 
Pesantren's history of development can be seen in two ways: 1) pesantren comes from a Sanskrit word meaning literacy; it is based on the social class asa leteracy class, one who attempts to dig into the books written in Arabic, 2) pesantren comes from the root of santri and according to the PE and sufice, which in Javanese is often referred to asa teacher no matter where a teacher goes [6].

Pesantren's Pesantrens were an islamic educational and teaching institution in which there was some interaction between kyai or ustadz asa teacher and santri asa student by taking place in a mosque or in the dormitory's pages to study and discuss the religious texts of past clerics. These textbooks are better known as the Yellow Book, since in the past they were generally written or printed in yellow paper. The mention continues even though many are reprinted in white paper. Thus the most important element to a pesantren is the presence of kyai, sanitians, mosques, resives, and books or books of the text [7]. Long before Pesantren was a nusantara educational system. In almost all the region of nusantara, especially in the center of the islamic kingdom, there is a similar educational institution, though using different names, such as shards in aceh, surau in minangkabau, and pesantren in Java. Nevertheless, the historical early arrival of the origin funds is still blurry. Many pesantren authors believe that this institution is the adoption of a school model hosted by hindus and buddhists as it is known. When Islam came to thrive on the island of Java there was a Hindu and buddhist school institute that used the convent and boarding system as a place where monks and monks were doing their learning activities for their followers. This kind of education is then a model for the guardians of islamic broadcasting and teaching activities to the wide community, taking the form of the convent and boarding system by turning isping into an islamic teaching known as pesantren hut.

Pesantren as the education institute that has ever emerged in Indonesia, is the oldest educational system today and is regarded as the product of the Indonesian culture the indigenous [8]. This education was originally an islamic religious education that started when the rise of the islamic community in nusantara in the 13th century. Some centuries later this arrangement of education was more orderly with the advent of places of presentation ("nggon ngaji"). This form then developed with the stance of lodging places for students (santri), later called Pesantrens. Though relatively straightforward, Pesantren was the only structured institution of education at the time, and this was considered a prestigious institution. It was at this institute that muslims in Indonesia were deeply involved in basic islamic doctrine, particularly involving the practice of religious life.

Pesantren was expanding rapidly with the non-cooperative attitude of clerics toward Dutch colonial "ethical politics" policies in the late 19th century. The policy of this colonial government is meant to pay back the indonesians a modern education, including western culture. But the education provided was very limited, both in terms of the number afforded an education and in terms of the level of education provided. The scholars' uncooperative stance and silent opposition was later indicated by establishing Pesantrens in areas far from the city to avoid colonial intervention and to provide opportunities for the unenlightened people. Until the late 19th century, in the exact year of the 1860's, according to sartono kartodirdjo's study (1984), the number of pesantren had reached 300 Pesantrens. J. a van der chijs report in 1831 on indegenous education reports that in cirebon there are 190 pesantren with 2.763 santri, in 9 Pesantrens, kendal 90 Pesantrens, demak 7 Pesantrens, and 18 Pesantrens in grogan. In kedu there are five schools that teach religion, while in cast there are a number of clerics who teach religion. Banyumas and the great one also recorded some religious schools and schools. While in surabaya there were 4. 397 santri students in 410 west cross. 34 ribs and covers about 500 ribs [9]. 
The ministry of religion data mentioned in 1977 boarding Pesantrens were still about 4.195 pesantren with a number of sanitizers around 677. 394 people. This number experienced a significant increase in 1985 , in which pesantren totaled about 6,239 with a number of santri approximately 1,084,801. Two decades later, 1997, depag recorded an increase in pesantren by $224 \%$ or 9,388 pesantren, and a rise in santri's number was $261 \%$ or $1,770,768$. The latest depag data in 2001 shows that this number of pesantren throughout Indonesia has reached 1312 pesantren with a total of $2,737,805$ people. This number includes salafiafides pesantren, traditional to modern. In addition to pointing out the level of the diversity and orientation of the leaders of kyai and independents or clerics, this amount reinforces the view that pesantren is a private-educational institution of very independent and totally community-based education. Nearly $100 \%$ of education in Pesantrens or schools is public and private property [10]. The second development, involving the provision of education. Since 1970 school forms organized by Pesantrens have been quite varied. Forms of education can be classified into four types, namely: (1) pesantren who conducts formal education by applying the national curriculum (mi, MTS, ma, and islamic religious pt) as well as public schools (sd, junior, high school, and general pt), (2) pesantren who conducts religious education in madrasah form and teaches general science despite not applying the national curriculum, (3) pesantren who only teaches religious science in the form of madrasah diniyah, (4) schools that are simply places of presentation.

All these changes, however, did not lift schools out of the culture roots. Pesantren generally remains a function: (1) an educational institution that transfers religious sciences (tafaqquh fi 'aldin) and islamic values (islamic values), (2) a religious society that practices social control, and (3) a religious society that conducts social engineering (social engineering)[11]. The pesantren types of differences above affect only the form of actualization of these roles. The first function is a primary Pesantren and is a major factor in the parents sending their young into Pesantren. While there is a growing tendency for parents to send their children to school in the public schools for reasons of finding work more readily, the reality is that new schools are still emerging. Aced from the institutional side, today some pesantren appear to be an institution ora campus with the full capabilities of facilities to build santri potentials, not only moral, value, intellect, and Sprite, but also physical and material attributes such as the advent of pesantypesantren, which are neatly packaged with modern equipment such as language laboratories, computer technologies and the Internet, and so on. By retaining the familiar characteristics and authenticity of the curriculum content, such as the sorogan and the bandana, some pesantren also adopted a formal classification system such as those found in the public school system.

\subsection{Heart Knowledge Management}

In the early days Pesantrens had different levels. The simplest Pesantren is simply teaching how to read the Arabic and the qur 'an. Meanwhile, a rather high Pesantren is pesantren who teaches various fiqh, science akidah, and sometimes amalan sufi, next to Arabic grammar (nahwu sharaf). Generally the Pesantren tradition is determined both now and then three courses of fiqh. According to mazhab asy 'ari and amalan-amalan sufi from the priestly works' alghazali.

A common feature known is that pesantren has a distinct culture that differs from the surrounding culture. Some researchers call an idiosyncratic subculture. His teaching too was unique. The kyai who was usually the founder and owner of pesantren, read classical religious manuscripts in Arabic (known as "Yellow Book "), while sanitians listened and gave notes (ngesahi, Java) to the book being read. This method is called bandstand. In this school, there is a pattern of education that is not in the school's formal education that is based on the principle of "seeing me kalakone kanthi sale" means it has to be done in action. That pattern is liver knowledge management. The transformation of knowledge into science is not through scientific 
codes limited to human thought but also involves knowledge of the heart. Facts are obtained by humans through logical reasoning using scientific and natural measures. The limits of reason are limited to man himself which put everything ahead but overcomes everything which is not the basis for what is. Knowledge of all these things is literally enveloped by man and yet selfishly ruled out. The knowledge of the heart encompasses knowledge of all that is devoid of knowledge of taste[12]. Such knowledge is framed in the reality of a human life made up of a sense of humanity, of life and of the universe.

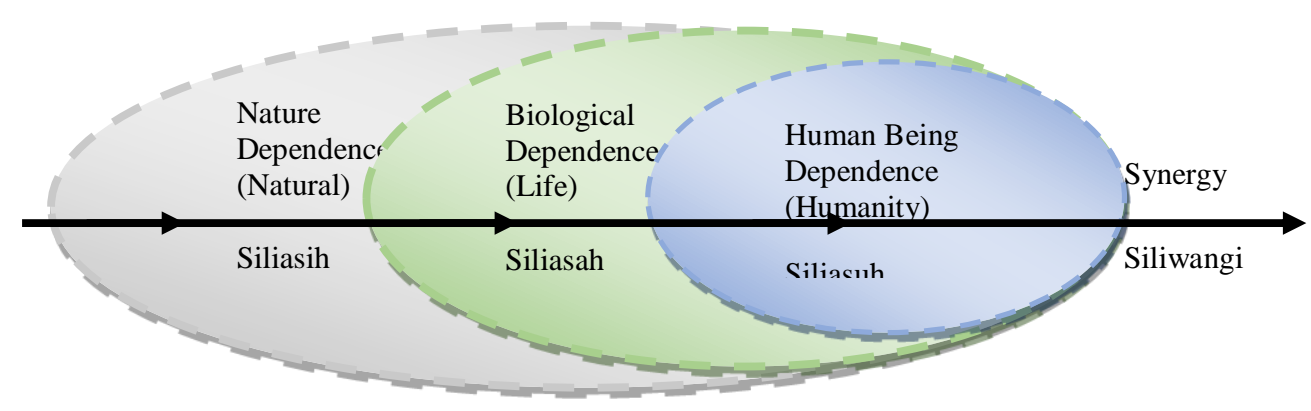

Fig. 1. A figure caption is The connection of humans, living things, and the universe.[13]

Hearts, by al ghozali in the book of ihya 'ulumuddin, are explained into two forms, First, the human vital organs that pumps blood in the body and Second, in the human spirit that is refined and linked him with his creator [14]. The first form of heart is a manifestation of the human body and the second form is a manifestation of the human soul. Both forms are inseparable and connected to each other.

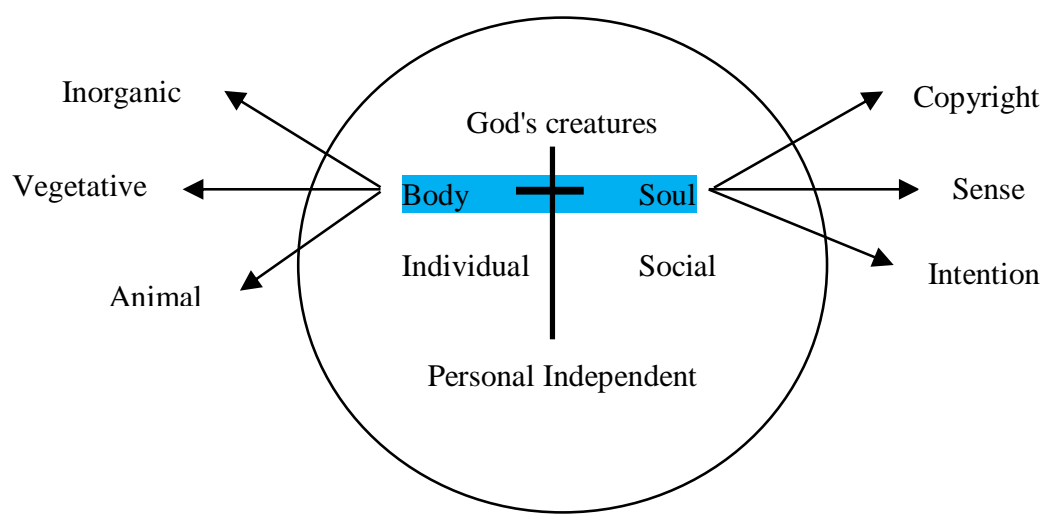

Fig. 2. A figure caption is the concept of body and soul.[15]

Through the heart, human has the power of creation, flavor, and carse in social life, while in life their main goal is happiness. Happiness has an attachment to the reality of the essential aspects of other living things and to the interests of complacency. Often humans achieve happiness through other joys and a sense of happiness that is more valid than that of happiness on the basis of self-satisfaction. But the various kinds of happiness have not been included into 
the nature of happiness, its nature is a sense of happiness itself and an unhappy feeling. In this sense of happiness, in Pesantren is taught and implemented how the human heart can identify all that is lost through the eyes of the heart. Clarity of all self-interest and focus on the creator will be enlightened. The enlightened of human heart is connected to all creation, and through such creation man's heart can go deeper and deeper to unlock the secrets of what is and what is not. Everything that existed is a manifestation of nothing and of creation. Every creation must have a creator, like humans, other living things and the universe must have a creator, too. The knowledge of the heart developed in Pesantren led the learbers not only to understand but also to understand the heart, and in the end of time, It becomes the means by which every human is able to recognize hisself in knowing his creator.

The management of the knowledge of the heart is started as a depersonification of the mind of everything attached to man, the clarity done with sense control primarily of sight and hearing. This process is passed by remembering Allah SWT in every second of his gasp, the implication in man is that his heart is open to embrace everything that is real or fake. The basic foundation of the heart knowledge management is his faithful toward Allah SWT who created either the real or unreal, mwanwhile the management structure of heart knowledge is the end of all education in schools that is meant for wisdom on the basis of knowledge of the real things or unreal things.

\section{Conclusion}

Heart knowledge management in pesantren consists of spritiual values based on islamic religious teachings, the local values developed in a confirmed society through thought, word, and action. Good thinking leads to good deeds. Good thinking is driven by an enlightened heart through the knowledge of the heart.

\section{Acknowledgement}

Interviews are given to the leader stkip pgri ulantly of the academic part that has facilitated this research.

\section{References}

[1] M. Sanprayogi and M. T. Chaer, “Aksiologi Filsafat Ilmu dalam Pengembangan Keilmuan," Aksiologi Filsafat Ilmu AL MURABBI, 2017.

[2] T. Dalgleish, J. M. G. . Williams, A.-M. J. Golden, N. Perkins, L. F. Barrett, P. J. Barnard, C. Au Yeung, V. Murphy, R. Elward, K. Tchanturia, and E. Watkins, "Kebudayaan,” J. Exp. Psychol. Gen., 2007.

[3] K. H. Dewantara, Ki Hadjar Dewantara; Pemikiran, Konsepsi, Keteladanan, Sikap Merdeka, 5th ed. yogyakarta: UST Pers dan Majelis Luhur Taman Siswa, 2013.

[4] Z. Dofir, Tradisi Pesantren, 1st ed. Jakarta: LP3ES, 2011.

[5] M. Van Bruinessen, Kitab Kuning, Pesantren, dan Tarekat, Revised. yogyakarta: Gading Publishing, 2012. 
[6] Nawawi, "Sejarah dan Perkembangan Pesantren," Ibda`| Vol. 4 | No. $1 \mid$ Jan-Jun 2006 |4-19, 2006.

[7] M. Syaifuddien Zuhriy, "BUDAYA PESANTREN DAN PENDIDIKAN KARAKTER PADA PONDOK PESANTREN SALAF," Walisongo, vol. 19, no. 2, 2011.

[8] M. Kholil, "Menggagas Pesantren sebagai Pusat Peradaban Muslim di Indonesia," Media Akad., vol. 26, no. 3, 2011.

[9] A. Basarudin, "KONSTRIBUSI PONDOK PESANTREN SALAFIYAH MIFTAHUL ULUM DALAM MEMBINA MORALITAS MASYARAKAT DESA SUKOLILO JABUNG," UIN Malang, 2008.

[10] Suheri, "STUDI TRANSFORMASI ELEMEN PONDOK PESANTREN," Islam Akad., vol. 8, no. 1, pp. 17-34, 2016.

[11] A. Muhakamurrohman, "PESANTREN: SANTRI, KIAI, DAN TRADISI,” Ibda', J. Kebud. Islam, vol. 12, no. 2, 2014.

[12] E. Bin Baharuddin and Z. Binti Ismail, "7 Domains of Spiritual Intelligence from Islamic Perspective," in 2nd Global Conference on Business and Social Science-2015, GCBSS-2015, 17-18 September 2015, Bali, Indonesia, 2015, pp. 568-577.

[13] M. Purwasasmita, "Fenomenologi Nilai," 2015.

[14] 1058-1111. Ghazzālī and Adi Setia., The book of the proprieties of earning and living = kitab adab al-kasb wa-al-ma'ash. IBFIM, 2013.

[15] S. Wreksosuhardjo, Filsafat Pancasila secara Ilmiah dan Aplikatif, 1st ed. yogyakarta: Andi Offset, 2014. 